\title{
New Social Practices in the Field of Museum Education in Brazil: Digital Culture and Social Networks
}

\author{
Dalton Lopes Martins, Luciana Conrado Martins, Danielle do Carmo
}

\begin{abstract}
The use of digital technology and creation of network infrastructures in Brazil's national museums has emerged as an important research topic in recent years, either from the perspective of finding new ways to socialize collections and to expand their potential or by implementing new practices to manage and organize these institutions. This article aims to debate how museum education sectors can establish new social practices of digital culture based on the perspectives identified by digital technologies. To this end, a reflection was carried out based on the educational potential proposed by the National Policy on Museum Education, and a case study was performed based on the experience of the Tainacan project, implemented by the Brazilian Museum Institute for the socialization of museum collections in the digital universe. The results are still preliminary; however, they can show how the practices of digital culture, considering that the network has its own characteristics and socialization strategies that are inherent to it, which can be used in favour of museum education, constitute operational possibilities, which can be applied in the reality of Brazilian museum institutions.
\end{abstract}

Key words: museum education; digital culture; social networks.

\section{Introduction}

The purpose of this article is to discuss the relationship between museum education and digital culture, through new uses of information and communication technologies and social practices carried out by museum educators to promote dialogue between museums and society in the Brazilian context. Therefore, we propose a reflection based on the concepts of museum education in Brazil and digital culture in contemporaneity. The article details specificities of the National Policy for Museum Education (PNEM) and how this has unfolded into experiences with the use of digital technologies within the Tainacan project, an initiative of the Brazilian Institute of Museums (IBRAM) for the socialization of museum collections in the digital universe. To that end, some questions will be considered, related specifically to the Brazilian context: What new possibilities could these practices offer for museum education? How might these possibilities interact with the management and socialization of museum collections? How can information networks be used to support these new socialization practices? How would museologists, and museology professors in particular, be trained, based on this scenario?

This perspective is in line with the possibilities provided by digital technology in museums. According to Vessuri, technology offers the public new museum experiences and expands forms of interaction based on established experiences. The same author reports that 'technological changes have also affected the expectations of visitors in terms of how they receive and contribute to information in the museum context' (Vessuri 2017: 51). As such, making museum heritage more accessible to a larger number of people by democratizing access is part of both implementing museum education and using digital technology in museums. Targeting the public provides new insight on twenty-first century socialization practices. Assessing digital devices as a means of producing and consuming museum information raises the question of how these new uses influence museum practices. New layers of socialization between museums and the public are now available for museum 
activities. It is important to underscore that these new possibilities are in no way opposed to promoting the physical presence of the public in museums. On the contrary, the social practices established by digital technology may in fact facilitate and encourage this access. Studies demonstrate that the number of local visitors to a museum may increase significantly when its collections are available online (Navarrete and Borowieck 2015). However, it is known that comprehensive access to these technologies is still a huge challenge, especially in countries with great social inequality, such as Brazil. Recent data indicate that there are around 134 million Internet users in the country, which represents 74 per cent of the population aged ten or older, with more than 47 million people still disconnected (Comitê Gestor da Internet no Brasil 2020). Currently in Brazil, it is not uncommon for questionable practices about the use of technologies and the internet to manifest, practices that are harmful to democracy and civil society, such as the enormous proliferation of fake news, conspiracy theories and attacks on the country's democratic institutions. It is understood, however, that museums and museum education can help qualify the use of the Internet and support the promotion of practices that lead to the development of critical and qualified capacity in the use of technologies. This is one of the inspirations behind the topic of our research.

Observing, therefore, the growing interest on this theme among important international research, it is necessary to better comprehend how these digital practices might be appropriated for educational work by museums, especially in the context of the relationship between and the mediation challenges of museum objects and their audiences. Furthermore, the ongoing social transformations resulting from the current coronavirus pandemic are intensifying the adoption of digital technologies for the practice of remote work in several contexts and different areas of activity. Understanding its impact on the work of the museum educator becomes urgent, to exercise the possibilities of the presence of museums as an institution on the Internet.

Thus, this article will present a qualitative reflection about the specificity of museum education as a field of study centred on museums and their processes, with its own unique characteristics, programs, projects and educational initiatives, and as an arena of autonomous knowledge production; and also about the uses and impacts of digital technologies on museum education, especially those aimed at understanding the effects and possibilities beyond merely implementing certain techniques and technologies. The article consists of a case study from Brazilian experience analyzing the concepts of museum education, digital culture and how they are being implemented in Brazil, based on observation of the National Policy of Museum Education and the Tainacan project of the Brazilian Institute of Museums.

The article is organized in four parts. In the first, it addresses the characteristics of museum education in Brazil with a focus on the National Policy of Museum Education. In the second, it discusses the concepts of digital culture applied to the context of museums. In the third part, the case study is presented, brought from the experiences of the Tainacan project in the museums connected to the Brazilian Institute of Museums. In the final part, the results are critically analyzed and a reflection is presented on the possibilities, the impacts of the uses of digital culture for education in museums and the training of museum educators.

\section{Characteristics of Museum Education in Brazil}

The specificity of museum education has become an important topic of investigation among researchers and museum professionals in the last decade. Highlighting the characteristics of museum education is part of an effort to establish it as an educational field and recognize it as a legitimate object of research.

The uniqueness of education, as an object of research and action in the field of museums, is manifested in Brazil through community initiatives and social participation, which resulted in the creation of community museums and heritage initiatives, supported not only by the concepts and ideas of the New Museology, but also by public policies that emerged in the re-democratization of the country from the 1980s onwards. During this period, several community museums, museums of favelas and eco-museums appeared in the country, which gained prominence and became a field of experimentation of new museum practices in which education started to play a preponderant role in the activation of the communities around heritage themes. 
Two important facts configure the Brazilian specificity of museum educational practices. The first of these was the repercussion of meetings of the international museum community in Latin America, for instance, the Santiago (Chile) ${ }^{1}$ Round Table, organized by ICOM in 1972, in which the social role of museology and the definition of the concept of an integral museum were discussed. This meeting had enormous importance in proposing a museum active in social development to overcome inequalities in the Latin American context. The resolutions adopted by the Round Table include specific issues on continuing education, such as the creation of educational services, the creation of a national education policy and the use of museum material for educational purposes. A second high-impact meeting in the context of Latin American museum education was held in Caracas in 1992, the Seminar 'The mission of museums in Latin America today: new challenges', organized by ICOM and resulting in the Caracas Declaration, which highlighted the importance of museums as partners in community development, with communication and education functions being essential to this process.

Over the decades, those meetings had an impact on the structuring of educational sectors of national museums in Brazil and the expansion of the museum educator as a profession, resulting in the construction of PNEM, launched by the Brazilian Institute of Museums in 2017 (IBRAM 2018). The National Museum Education Policy was built collaboratively with the active participation of museum educators and civil society, and it defines guidelines and principles for the implementation and structuring of museum education in the country. For this purpose, the policy is composed of five principles and three axes, in which guidelines are defined for management; professionals; training and research; and museums and society.

Another important fact in relation to the specificity of museum education in Brazil is its close relationship with the educational ideas and practices of the pedagogue Paulo Freire (2013), who points out the importance of education through dialogue between educators and students based on their social experience and context. Museum education is, in this sense, one of the resources that acts in transforming heritage safeguarded by these institutions into the cultural heritage of society (Bruno 1996). A critical education perspective is assumed here, supported largely by Freire's (2013) conception, in which education is understood as a tool that liberates the learner who is in search of a better and fairer society. The heritage kept by museums is, within this pedagogical view, understood as a source of information and critical discussion promoted through various educational activities imbued with this transforming potential (Lindauer 2007).

From these disparate elements, the importance of recognizing the communicational and dialogical practices as possibilities for the structuring of educational actions is emphasized. In Brazil, this has been translated into museum educational practices in which the public guides what will be treated by the educator from their expectations and interests, within a perspective of shared authority between educator and student. It is worth mentioning, for example, Guideline 6 of the Museums and Society axis of the National Museum Education Policy, which encourages the use of new technologies, new media and digital culture in stimulating and expanding the exchange of experiences between museum and society.

As a result, exhibitions, educational initiatives, and other activities aimed at the public became increasingly relevant and important (Hooper-Greenhill 1994) in contrast to the typically preservation-oriented practices of museum operations (Bruno 1996; 2010).

Despite tension in the museum sector as a result of this shift, education has gained increasing significance in Brazil as both a topic of research and knowledge production, and as a practice within museums and their processes. The potential of museum education to disseminate and appropriate the heritage safeguarded by museums is widely reported in the national literature (Cazzeli et al. 2003; Bizerra 2009; Martins 2011; among others). The importance of museum education in recent decades is also related in part to public studies that corroborate its significance in creating more democratic, plural museums that are accessible to all types of visitors (Almeida et al. 2003).

In this sense, as the result of those transformations, the definition of 'education' presented in the National Museum Education Policy by Costa et al. (2018: 73) states that:

Museum Education involves a series of unique aspects, including its own content and methodologies; learning; experimenting; stimulating interest and intrinsic 
motivation through direct contact with museum collections; acknowledging and welcoming the different meanings produced by a diverse audience of visitors and how they experience the museum; producing, disseminating and sharing specific knowledge related to the different collections and museum processes; encouraging appropriation of historical culture, a feeling of belonging and a sense of preserving and creating individual and collective experiences.

Among the different aspects identified by the authors, contact with the heritage housed in museums is highlighted as unique to museum education, as well as the experience of being in museums and diffusing specific knowledge on their collections. More than simply conveying knowledge, museum education revolves around interaction with the public, both actual and potential visitors. In this regard, Aidar and Martins (2018: 168) discuss the concept of museum education as understood by professionals in Latin America, as follows:

The public plays a pivotal role, both as catalyzers and targets of the activities developed by these institutions, which is evident in the statements made [by professionals in the area]. This broad notion of the museum's role and the power of its relationship with different audiences is clear in their answers regarding the meaning of educational action, which differentiates museum- from school-based education, each with its own unique audience.

Along these same lines, L.C. Martins (2018), in addressing the possibility of the existence of a museum education curriculum, identifies the characteristics, objectives and needs of visitors as the main factors that shape museum education initiatives.

Historically, museum education has become one of the processes that favours communication between museums and society. Views on the role of museology professors have changed over time, with educational departments in the field currently responsible for countless activities aimed at understanding and communicating with a wide range of audiences. Roberts (1997) debates the growing importance of educational sectors in today's museums and emphasizes that the role of contemporary educators extends beyond simply teaching. According to Roberts, 'they are involved in a whole series of activities broadly related to education and audiences, including devising programs and exhibitions, school field trips, teacher training, continuing education, science outreach, managing volunteers, public studies, and fundraising' (Roberts 1997: 2).

These different roles were consolidated from the early twentieth century, when museum education gradually began to gain ground in relation to other museum-related functions (Valente 2003). It can be observed that in Brazil the same has been occurring, with considerable growth in the role of educators and the importance of education in the context of museums.

In this respect, educational practices are based on the perception of museums as spaces for the socialization of knowledge and democratization of access to the cultural heritage of humanity. The idea of the museum as an educational arena, with the public at its centre, links the social relevance of these institutions to their ability to educate their audiences (Hooper-Greenhill 1994) and compete directly with the view of museums as spaces dedicated primarily to storing, studying, and conserving their collections.

The museum authority within this educational perspective is shared, whether in the conception of the discourses on collections or in the very selection of what will be preserved by the institution. Historically, it is through educational actions and the work of educators with different social groups that these possibilities of public engagement around preservationist decisions are established. However, one may ask, in which way this vision of educative actions relates to the perspective of digital culture? Undoubtedly, it is a point to explore in further research, due to its importance and coverage. Nevertheless, it is understood in the present research from the perspective of the museum educator's performance as a content curator and, more than that, as a producer of informational networks, establishing connections, mediating access, developing informational exhibition strategies and, above all, building pedagogical experiences of experimentation that treat museum objects as digital objects.

Digital culture aligns with this scenario, proposing changes in how audiences relate to museums. In this regard, it is important to reflect on how the use of technology might impact 
the educational mission of museums. It seems that the National Policy of Museum Education, as well as the research field of museum education in Brazil, establish the parameters and principles not only for the exchange of experiences between museum and society, but also for the promotion of collaborative actions with communities, encouraging reflection and collective construction of critical thinking. Digital culture, in this sense, reveals itself as a possibility of the empirical manifestation of such principles.

\section{Digital Culture: Elements to Consider for Museum Education}

There are currently a large number of researchers discussing the importance of digital culture and digital objects for museums. Cameron (2010) proposes that digital objects must not be considered inferior representations in comparison to physical objects. Rather, they must be understood as a new reality operating in a new 'space of enchantment'. The potential qualities that this new space proposes become a matter of special importance for museum education from a digital perspective. Geismar (2018) discusses lessons learned from the analysis of museum objects in the digital age. Based on the idea that the way objects are treated must be considered in order to understand the processes of knowledge construction, Geismar (2018) updates the idea of the museum as a contact zone and incorporates digital space as one for socialization, meeting and contact with objects, inviting the exercise of new museum practices in this space. Winesmith and Anderson (2020) argue that the digitalization of museum collections is an important step not only to supporting the presence of these institutions on the Internet, but also to recognizing their relevance as cultural institutions in a society which relates and organizes itself in a network. Finally, in an important handbook recently published, Lewi et al. (2020) define 'digital practices' as ways to think and work with data, information and digital artefacts and infrastructure, existing in a context of constantly transforming work profiles in the field of museums and other culture institutions.

In summary, what is observed is the perception that a society that increasingly relates through digital networks, expanding the experiences of telework, distance education, the use and the offer of digital public and private services, in addition to all strategies and possibilities of electronic commerce, raises the digital space to a high degree of importance as a strategic element of social organization. In theory, occupying this space presupposes the elaboration of ways of being in a network and producing networks. What this discussion is intended to highlight is that museums can't avoid acting in these spheres of socialization, of high social relevance; they should recognize the need to deal with the phenomenon, through concrete cases and examples of how this has been done and how it could be improved for the development of work in the area. We believe that the principles of museum education can serve as a guide to orient museums towards the possibilities of digital culture.

In this discussion, more than simply defining digital culture, it is essential to reflect on how to observe its effects and how this might contribute to museum education research and practice. In this respect, one aspect to consider in the digital culture phenomenon is the socialization of information:

By viewing culture as an environment of possible meanings that allows us to observe continuously changing social practices around different forms of socialization of information, 'digital culture' can be considered a set of unique social practices that occur in the digital social space. The notion of singularity is important in digital culture because some practices can only occur in this social space and are ultimately inherent to its conditions (possibilities and constraints), whether these are technical practices related to the environment in which they occur, or social practices linked to the type of interaction used to socialize (D.L. Martins 2018).

This statement encapsulates an aspect directly applicable to the museum education scenario, namely the technical conditions of new forms of socialization of information, allowing new types of interaction that will be analyzed and contextualized here. Information mobility and the increasing capacity to generate this mobility, characteristic of digital culture practices, provides countless possibilities of socializing this information that may be directly applicable to 
the field of museum education. When addressing the concept of subsidiarity, Varine (2013: 19) appears to address this possibility directly when he explains that 'heritage should be managed as close to its creators and holders as possible (...). The role of specialized institutions is to raise awareness, facilitate, educate, make available, publicize, and manage for the common good of the general public'.

The technical condition of this information mobility that broadens the social possibilities of contact is based on the concept of hypertext. This phenomenon is still developing as a social power in the twenty-first century within a network society and will have significant implications in reorganizing traditional forms of knowledge production in almost all areas of knowledge. According to Barbier (2018: 364):

[...] Data is no longer structured linearly and hierarchically (as in printed text), but rather on a 'screen', allowing users to 'click' on a word or group of words to access new information, which itself is multimedia and therefore uses images and sound. The reality of hypertext has mobilized practices linked to the construction and availability of knowledge.

This mobility not only allows more information to circulate in the network, but also has enormous potential in educational processes, with the possibility of producing new knowledge by connecting and recombining pieces of information never combined before and generating potentially creative effects when faced with new forms of observation, novel points of view and unique ways of understanding phenomena. Burke (2012: 113) refers to this possibility as a form of bricolage:

Rather than one-way transmission, it is more useful to think of the circulation of knowledge in terms of the 'negotiation' of information and ideas or in terms of dialogue (on occasion, a dialogue of the deaf). One important implication of this view is that the distinction between producing new knowledge and transmitting old knowledge is necessarily blurred. Innovation is often a kind of bricolage, a reconfiguration of knowledge that results from an encounter between cultures.

In summary, digital culture brings two fundamental elements that we highlight for the contemporary structuring of new practices of museum education. The first of these is this possibility of bricolage as mentioned by Burke, that is, the ability to edit, reuse, modify and, above all, to create educational narratives from digital collections, which can be appropriated and reappropriated in infinite ways by educators and the public of museums. The second element is the capacity to enhance the circulation of information, providing means for educators to socialize museum information in different conversation networks present in the digital universe, potentially reaching users who not only do not know the physical museum, because they do not have access to it, but who may be interested in the information selected and shared by educators. In the next section, we will present how this scenario has been developed in Brazil based on the experience of the Tainacan project, of the Brazilian Institute of Museums.

\section{Tainacan Project: perspectives for the merging of digital culture and museum education in Brazil}

The creation of the Tainacan project by the Brazilian Institute of Museums is based on the idea of providing a technological solution for the dissemination and interoperability of digital collections, which is consistent with the scenario of Brazilian cultural institutions. For this purpose, it was developed as an open source, easy to use and able to promote the integration between different types of cultural collections (museums, libraries, film archives, among others).

Tainacan appeared in 2014 as a research project in the field of information science. The project has been developing its research, offering cultural institutions not only free software with the capacity to house and make available their digital collections, but also, mainly, a space for networking among these institutions. From 2014 on, the project would be implemented in the museums of the Brazilian Institute of Museums, as part of the Acervos em Rede Program. Currently, 16 of IBRAM's museums already use Tainacan ${ }^{2}$ in the dissemination of their collections. 
Over the past few years, the Tainacan project has gained the support of important Brazilian cultural institutions and started to be implemented not only in several museums, public and private, but also in institutions responsible for fundamental collections of national culture, such as the National Foundation of Arts (Funarte) and the Museum of the Indian (Funai). In addition, several public and private universities have used the Tainacan for the organization of their museological and/or scientific collections, and also for the training of professionals in museology courses. ${ }^{3}$ Among the international initiatives, the partnership with the General Direction of Information and Communication Technologies of the Secretary of Culture of the Government of Mexico stands out. They decided to use Tainacan as a repository of digital collections for the data providers of the Mexican platform. The project allowed the dissemination of different experiences related to digital collections and museum education practices. In order to simplify the presentation of the experiences, they were systematized into four practice groups discussed below. D.L. Martins (2018) identifies four forms of culture linked to the concept of digital culture, namely: hyperlinks, instant messaging, timelines and algorithms.

Hyperlink culture is a social practice that connects digital objects whereby people can communicate via links, such as sharing magazine and newspaper articles or videos on social media or writing blogs that refer to other digital objects using links. The process of establishing a link exemplifies the act of connecting digital objects by inviting people to use specific connections that they are exposed to on a daily basis, for example, reading instant messages via the WhatsApp application. As part of this process, people are exposed to a variety of links selected and shared through their personal contacts and any groups they are part of. These are generally followed by contextual information that explains the reasons for circulating and sharing these objects. In this respect, digital objects are manipulated, selected, shared, and contextualized and comprise an archive of symbolic content that becomes a cultural reference in everyday society.

To exemplify this practice, we will analyze the case of the Victor Meirelles Museum, which belongs to the Brazilian Institute of Museums and which makes its digital collection available within the Tainacan project. The museum published in its digital repository the work Estudo de traje (Study of costume) by the artist Victor Meirelles, as well as the museum documentation that contextualizes it. The digital work available can be seen in figure 01 , with the original documentation in Portuguese.
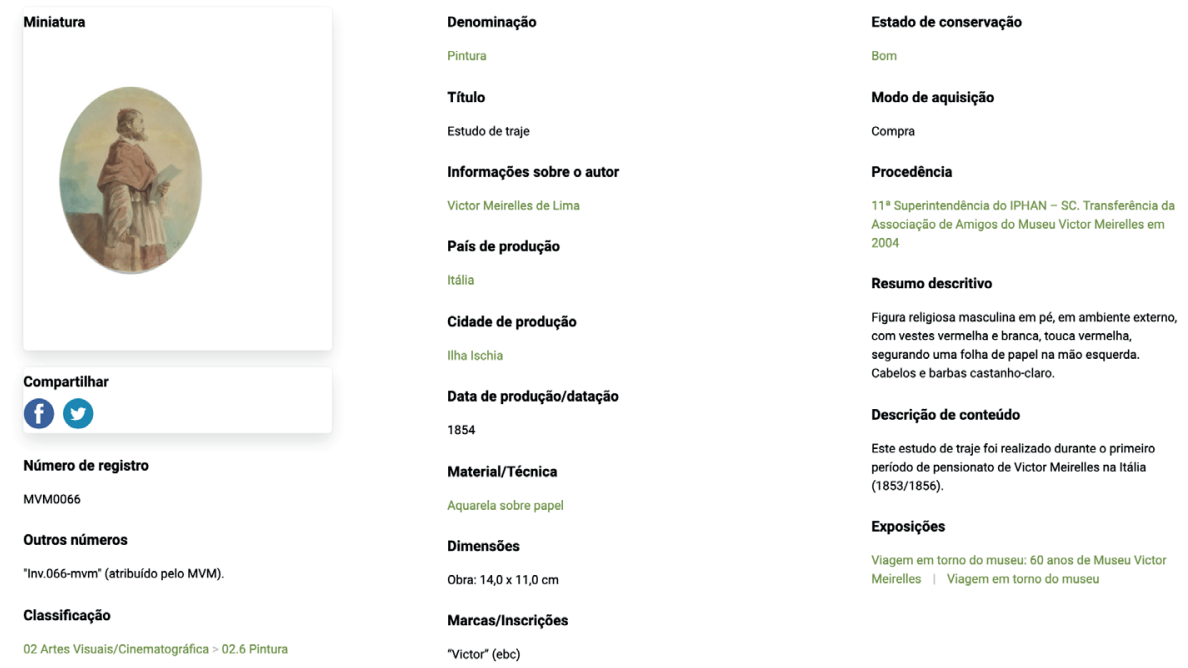

Figure 01 Catalographic file of the work Study of costume. Source: $h$ ttp://museuvictormeirelles. acervos.museus.gov.br/mvm-acervo/estudo-de-traje-57/ 
From the moment that the work exists as a digital object it is liable to be socialized through its hyperlink in different and diversified information networks. In this case, the work was socialized in the Wikimedia network, as can be seen in figure 02 , where the original link of the digital object is highlighted.

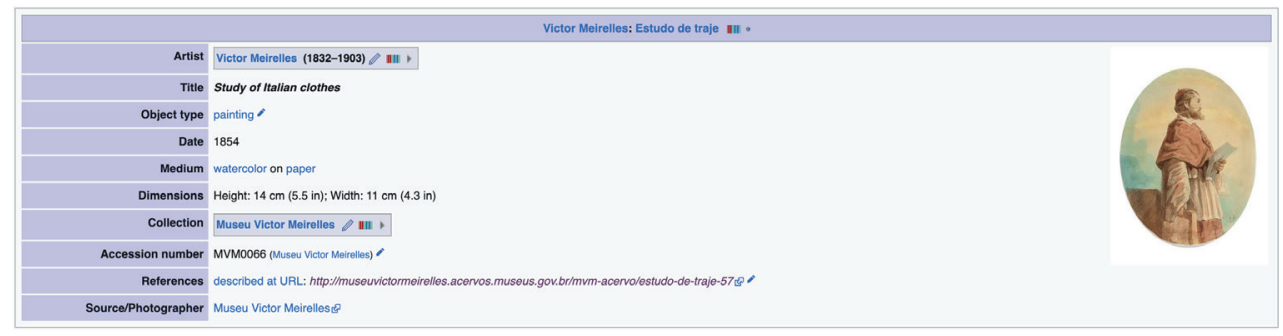

Figure 02. Summary of the digital object of the work Study of costume on the Wikimedia network. Source: https://commons.wikimedia.org/wiki/File:Victor Meirelles__ Estudo de traje italiano 19.jpg

It is important to highlight that by entering an information network of enormous visualization and Internet access, such as Wikimedia Commons, the digital object representing the item in the museum's collection will circulate in a network of broader scope and relevance than the museum's own digital repository, potentially reaching thousands of people. One of the roles to be performed by the educator is precisely to carry out the curatorship of which works will be socialized in which networks, putting the institution's collection in circulation in different circuits. It is worth emphasizing that this is a practice of contemporary museum education. According to data from the GLAMorgan ${ }^{4}$ tool, this image had, in September 2020, a total of 167 views, remembering that in that period the museum was closed due to the world pandemic of Covid-19.

By making the digital object available in information networks, it can be reused in other formats for the creation of new curatorial products with potential educational purposes. This is the case of a list created in another information network, Wikipedia, of all the works by the artist Victor Meirelles, where the digital object previously shared in Wikimedia Commons appears, as seen in figure 03.

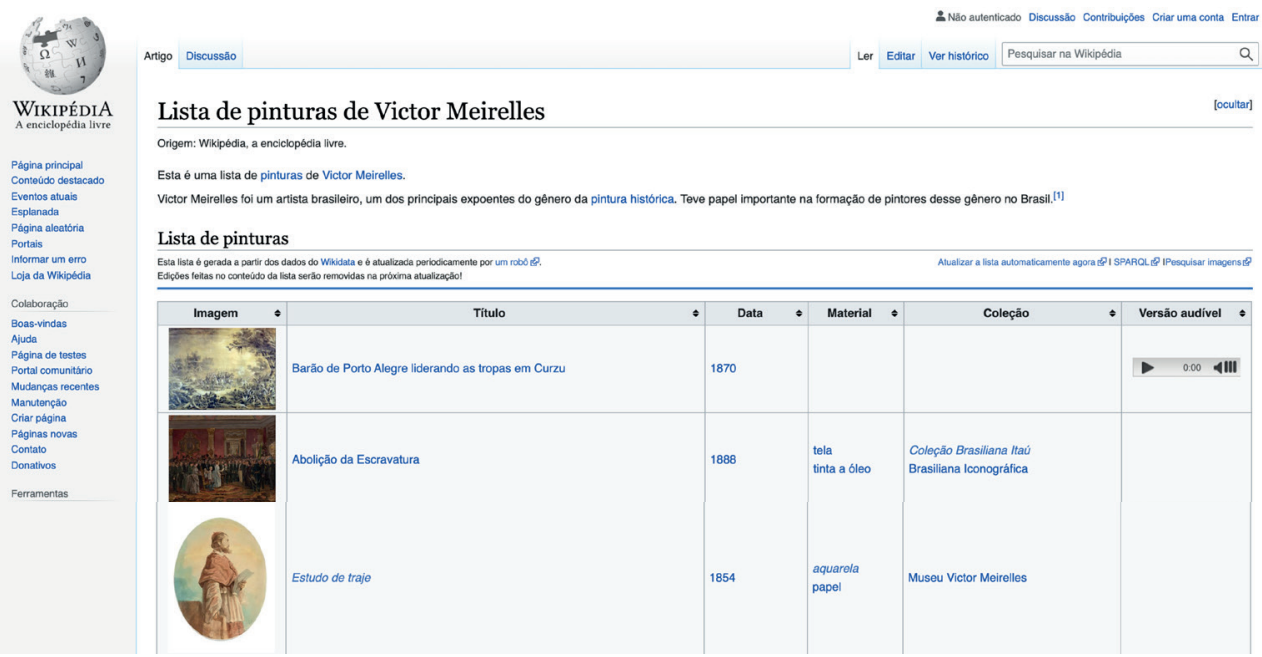

Figure 03. List of paintings by VictorMeirelles in the information network Wikipedia-highlighting the painting Study of Costume. Source:https://pt.wikipedia.org/wiki/Lista de pinturas de Victor Meirelles 
According to the Wikipedia ${ }^{5}$ page views tool, this list of paintings had a total of 288 views between 26 October 2020 and 24 January 2021. Once again, it is worth remembering that the museum was closed during this period.

The second practice to be considered, instant messaging culture is a temporal dynamic used in contemporary communication. Messages arrive and, depending on the receiver's availability, can establish synchronized communication flows where interaction occurs in real time. Both the temporality of this process and the type of digital objects it carries are characteristic of digital culture. Multimedia content, such as text, audio, video, and animations, among others, can also be included in the messages. Signals used in these messages are also considered characteristic, with sounds, vibration or visual signals demanding the attention of receivers and intervening in the circulation flow.

Here we shall see again an example from the Tainacan project, but this time related to the National Historical Museum. In a group of the social network WhatsApp, composed of 111 professionals in the field of museology from all over Brazil, including students, teachers, technicians and managers, there is an intense daily conversation about museology and the issues of Brazilian museum heritage. It is not uncommon to share links of experiences and projects that publish and disseminate digital museum collections. When the collection of coins and gold bars of the National Historical Museum was made available on the Tainacan platform, specific content was produced to circulate in instant messaging applications, such as WhatsApp and Telegram, by the institution's team of museologists. This content involved a podcast, with an interview with the museologist specializing in the numismatic collection.

The interview was transcribed in digital text format and the collection was made available as a link from the digital repository, as can be seen in figures 04,05 and 06.

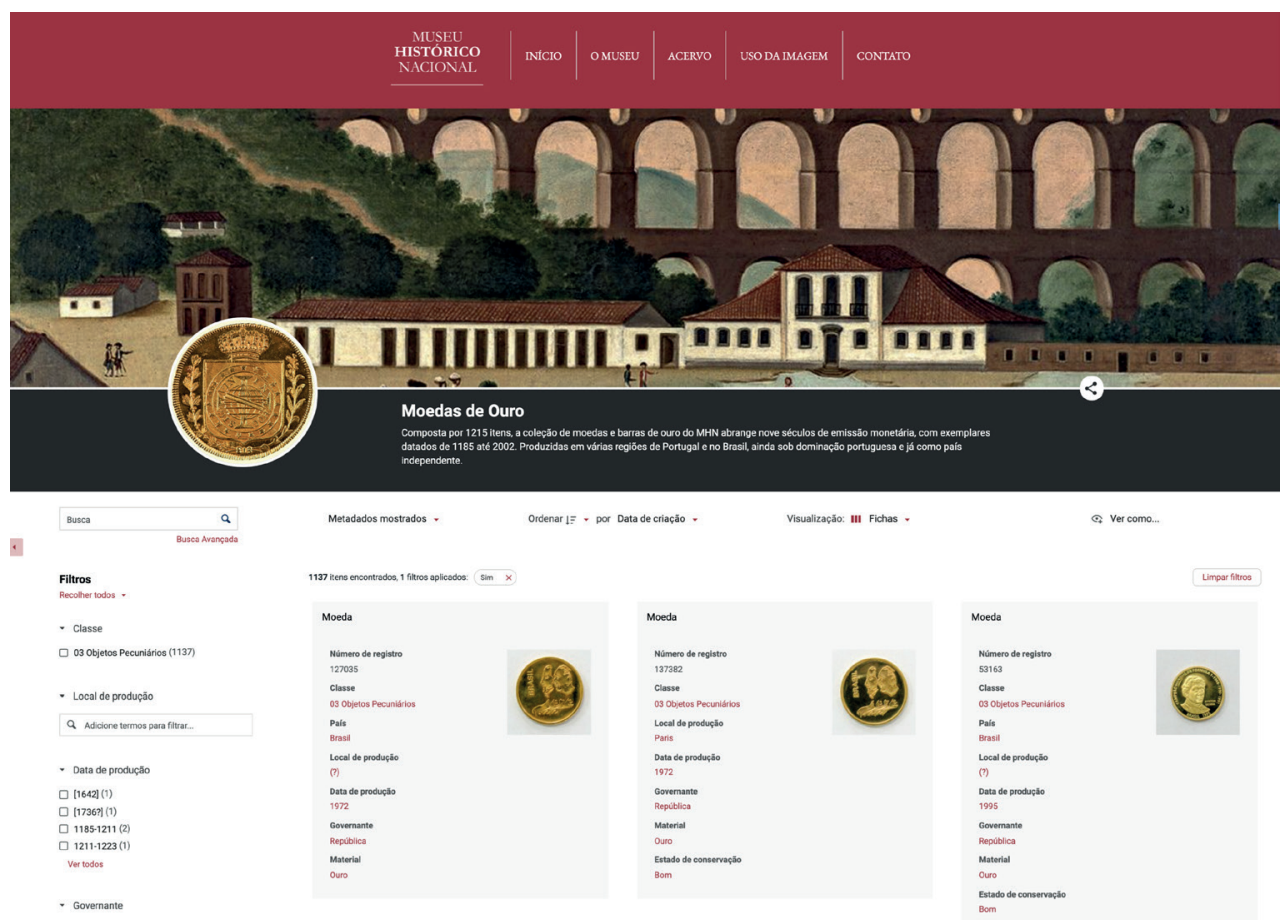

Figure 04. Gold Coins Collection of the National Historical Museum available on the Tainacan platform. Source: http://mhn.acervos.museus.gov.br/moedas-de-ouro 


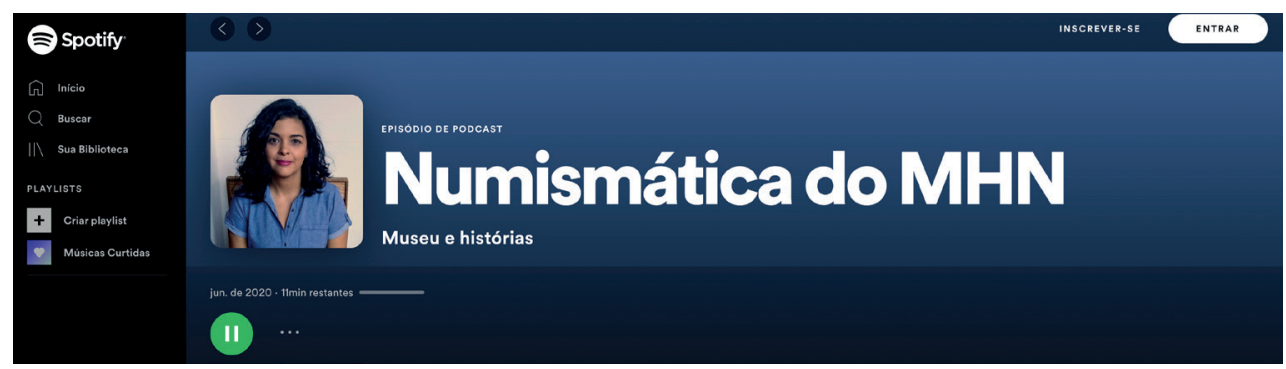

Figure 05. Podcast about the collection of Coins and Gold Bars. Source: https://open.spotify. com/episode/2EEjJgPD8F3w1PCmiisThU

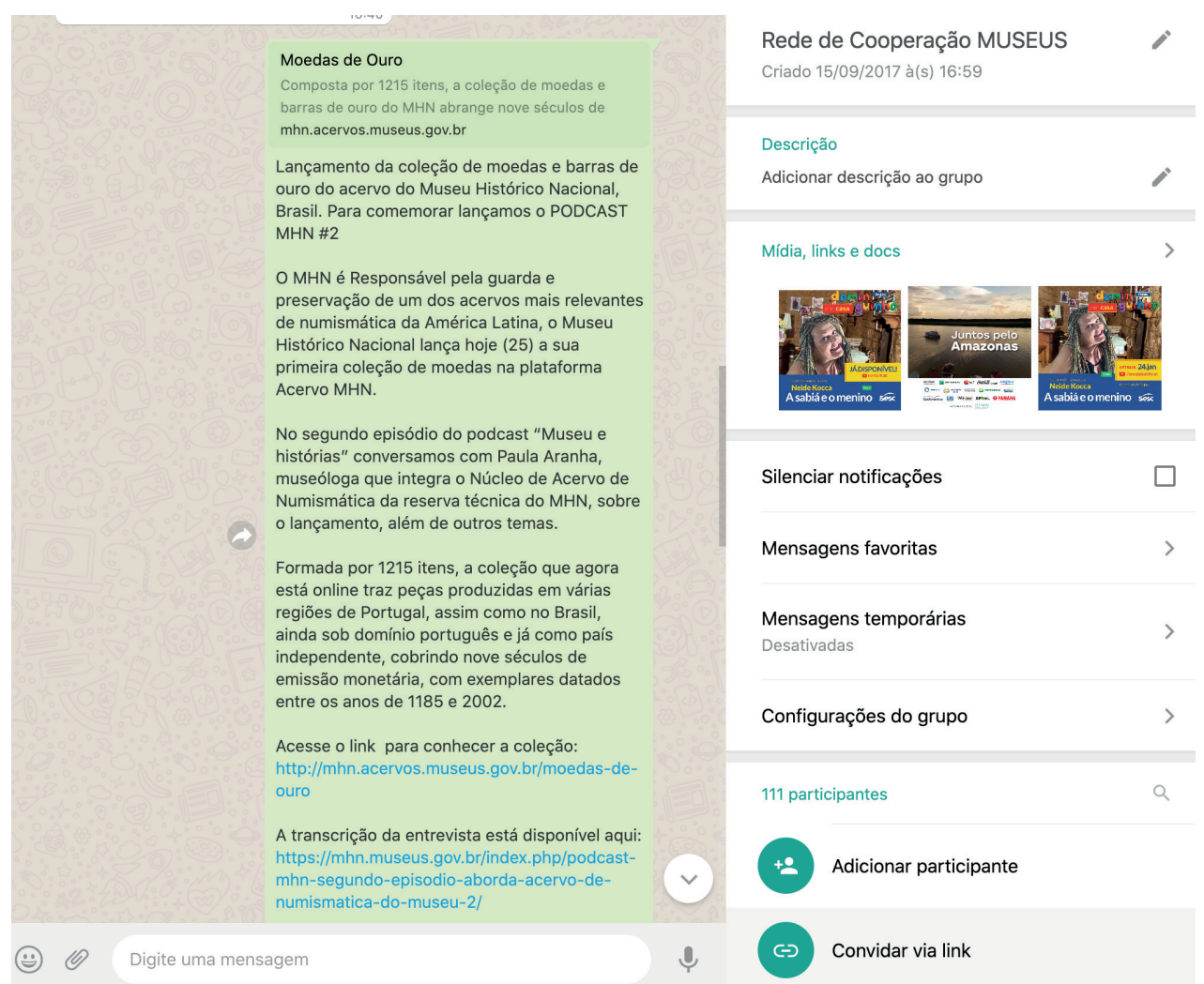

Figure 06. Digital collection and podcast sharing messages in the Museum Cooperation Network WhatsApp group. Source: research data.

As far as museum education is concerned, a podcast with educational content was produced highlighting pedagogical aspects of the collection of coins and gold bars of the National Historical Museum. This podcast is available in online aggregators (Spotify and Apple podcast, among others) and can be accessed online by the platforms themselves and by users spontaneously interested in the topic. However, it is important to highlight here the role that the museum educator can play as an amplifier of the pedagogical potential of this content by sharing it in a WhatsApp group with 111 museum professionals from all over the country, delivering curated content to audiences with potential consumer interest and the capacity to redistribute 
and amplify its reach, generating potential network effects, in addition to promoting dialogue and debates on the subject.

The third practice to be highlighted, timeline culture is a dynamic used to observe how information and communication is organized. Messages arrive and are stacked on top of each other so that the first ones delivered are less obvious to users, who will have to scroll down to see them. This feature is present in almost every social media application and means that new, current, and recently published information is always prioritized, making it more difficult to access older, previously displayed information. This has a significant impact on how modern-day communication is organized because it demonstrates how people will be directed to visualize and interact with the information they receive. Another important feature of this practice is the difficulty in searching for and recovering information: finding content visualized in the past can be a frustrating, complex, and difficult task because the technologies involved do not prioritize these functions but, rather, immediate information consumption instead.

We illustrated this practice from the Facebook page of the Brazilian Institute of Museums, when the links of the digital repositories of their museums were made available on the Tainacan platform. It is worth mentioning that the institute's page has 51,025 followers (data from January 2021) ${ }^{6}$ and therefore a considerable number of Facebook users potentially interested in the subject. Right at the beginning of the Covid-19 pandemic, still in March 2020, the institute posted information about the digital collections of its museums which, because of the strength of the network formed by the institution, was shared 231 times and 'liked' 216 times, generating comments among users, including new users that possibly do not follow the institute's page, expanding the reach and knowledge of digital repositories. This post can be seen in figure 07 .

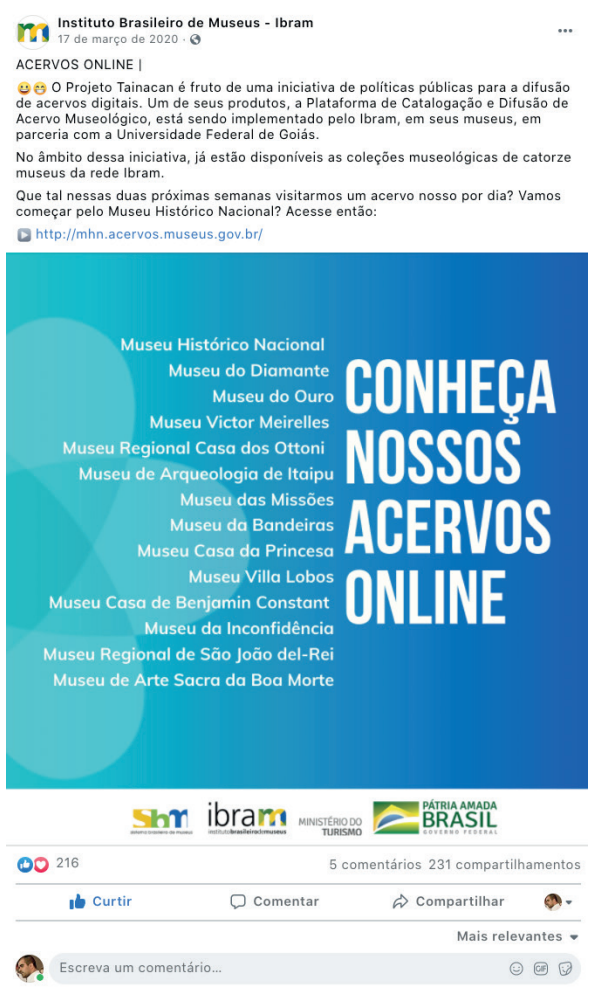

Figure 07. Post on Facebook to promote the digital collections of the Brazilian Institute of Museums. Source: https:// web.facebook.com/MuseusBR/ posts/3220928027934918
Educationally, one notices in this case the great potential of networking and establishing dialogue, engaging new users around the themes of the museums' digital collections. The role of the educator here is to encourage this dialogue, pedagogically improving the conversation, providing information, complementing it with new links and other digital content, enhancing the content and generating an improved and contextualized debate about cultural heritage. Again, it is important to stress that this post comes at a time when museums were closed and without public access.

The final form discussed in this study is algorithm culture, understood here as mathematical and computer calculations used to select and filter what different users will see. The important aspect in this culture is the criteria of these calculations, that is, which elements of the user experience are taken into account in order to establish, often without an express indication of interest, the content they will be exposed to. Current algorithms consider several attributes, such as content that users 'like' the most, comment on, share and watch. This information is used to create a digital profile of users and filters content to show them what they most enjoy. In fact, this practice highlights the overwhelming social inequality between those who create algorithms and define how they make calculations and those who are exposed to them via the digital applications they use, which has significant implications for the debate on questions of culture. 
In order to exemplify the practice and the effects of the algorithm culture, we return to the case of the Victor Meirelles Museum, using an experience with the Google search engine. Depending on the search term, Google can generate a summary table, known as the knowledge panel, ${ }^{7}$ showing contextual information of most relevance to the subject. This information is generated by Google's algorithms, consulting sites of great reputation and relevance on the Internet, such as Wikipedia. In the following case, we show the experience of a user who searches for information about the artist Victor Meirelles and how Google responds with a knowledge panel shown in figure 08.
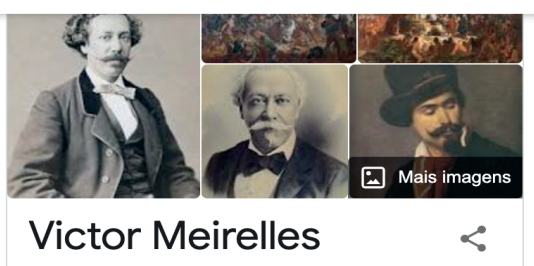

Pintor

Victor Meirelles de Lima foi um pintor e professor brasileiro. De origens humildes, cedo seu talento foi reconhecido, sendo admitido como aluno da Academia Imperial de Belas Artes. Wikipédia

Nascimento: 18 de agosto de 1832, Florianópolis, Santa Catarina

Falecimento: 22 de fevereiro de 1903, Rio de Janeiro, Rio de Janeiro

Em exibição: Museu Nacional de Belas Artes, Pinacoteca de São Paulo

Períodos: Romantismo, Academicismo

Formação: Escola de Belas Artes - UFRJ

Nome completo: Victor Meirelles de Lima

Morte: 22 de fevereiro de 1903 (70 anos); Rio de Janeiro, Distrito Federal
Obras de arte

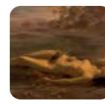

Moema 1866
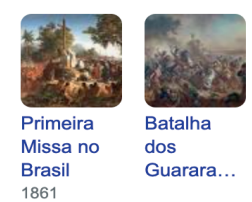

dos

Pesquisas relacionadas

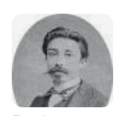

Pedro Américo

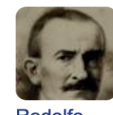

Rodolfo Amoedo

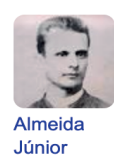

Ver mais 2

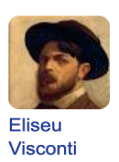

Feedback
Google's algorithm identified contextual information about the artist Victor Meirelles, such as his date of birth, his date of decease, and the artistic period that he represents, among others. It also indicates some of the artist's works and, highlighted in figure 08 , points out a related result indicating specifically the museum's website. The contextual information presented comes from sites such as Wikipedia, emphasizing once again the importance of providing relevant cultural information in these information networks. Google makes this content more accessible and delivers it in a more intuitive way to a user in search of a theme. Additionally, the museum can only be indicated as a search result because it exists as a digital presence on the Internet, and because its collections are presented in an organized manner in the Tainacan digital repository. Therefore, there is a relationship between digital information systems here of major importance for the cultural field. Thus, the museum provides a website and makes its digital collection available in this environment. This collection is published in information networks like Wikimedia Commons and Wikipedia. This information is collected by Google's algorithms and presented to users interested in the artist in an accessible and intuitive way, not requiring them to go explicitly to Wikipedia's website or even the museum's website to do their search. The algorithm takes the museum to the user.

The role of the museum educator is, in this context, to promote the articulation between these digital networks and generate informational layers of educational possibilities related to the collections. By incorporating museological documentation into the pedagogical reading of the collection, educators can share this documentation in the different networks of information, amplifying the potential circulation of the collections and facilitating its understanding by the users who perform searches mediated by the algorithms of the search mechanisms. There is here the possibility of creating a cycle of circulation and appropriation of information. However, for this cycle to work, the educator must understand these

Ver resultados relacionados Catarina
Figure 08. Google Knowledge Panel about the search 'VictorMeirelles'- the reference to the Victor Meirelles Museum is highlighted. Source: https://g. co/kgs/crs Xn3 
networking mechanisms, their effects and how to act on them. This requires an empowering of museum educators in order to expand the possibilities for the public enjoyment of heritage.

Analysis of the four social practices discussed here raises the question of how to deal with them, not only in terms of adapting to their features, but primarily in creating unique and specific interventions and experiences that can use these characteristics in museum education. To that end, the first and most vital step is for museums to reflect on which digital objects they would like to make available to their viewers. The next step should involve examining documentation on museum collections, digitizing physical objects, compiling digital repositories, and producing new layers of information about them, offering specific contexts in which the museum would like to present these objects and allowing possible interaction with them. In other words, the possibilities of the educational use of objects could, among other aspects that focus on the socialization of items in the collection, become a part of museological documentation, including information that can be added to the digital object. In this respect, documentation is no longer focused on managing the collection and begins to take on the characteristics of a digital object with the aim of promoting learning and the socialization of this same collection. Without this initial organization and a specific plan for museums to reflect on their ideal digital objects, what they intend to do with them and how the objects can be used for educational strategies, any other practices would become almost unworkable or too complex to implement. In this respect, educators can and should play an important role in defining and organizing this information, since they are responsible for an essential part of the socialization and public appropriation strategies of museum content (Martins 2015).

Finally, it is important to highlight a broad field of research and experimentation in the form of new algorithms and computational logic for curating and filtering relevant content, which could be explored as a means of providing users with relevant digital objects. Systems that prioritize educational interests and the importance of memory, cultural traditions and perspectives could be incorporated into computational logics that differ from current algorithms, providing new forms of interaction and distribution of digital objects.

\section{Conclusion}

The fields of digital culture and museum education have enormous potential for exploring the new social practices described here. Digital culture, with its technical particularities and specificities, provides opportunities for the appropriation of digital objects through new forms of socialization, allowing inventiveness to be explored based on the flexibility and malleability of these objects. In turn, museum education also exhibits a set of specificities and is strongly linked to museum collections and the proposed idea of creating strategies to facilitate their appropriation based on educational practices.

On the one hand is the possibility of educating using collections, and on the other, of converting these collections into digital objects and employing a set of new social practices aimed at expanding the potential of socializing these objects. This prospect affects the very concept of museum education which, in the wake of a broader view of museums and their heritage enhanced by discussions that brought the idea of integral museums into museology (Varine 2013), may provide a new understanding of its specificity. The potential uses of new socio-technical digital devices provide educational teams at local museums with the possibility of practising in unconventional spaces (digital networks) at a time when actual visits to museums are less common, of reshaping the idea of digital objects, and even of what constitutes intangible heritage. Time, space and object, the classic elements identified by Van Praët and Poucet (1992) as components of museum education, can be expanded and transformed by the possibilities provided by digital culture. Although the confines of this article do not permit a more in-depth discussion, it is important to reflect on how the impacts of digital culture on the practice of museum education could transform the specificity of this field. ${ }^{8}$

However, in order for this to be implemented in the field of museum education, these institutions must incorporate the technical dimensions of producing, manipulating and managing digital objects in training museologists, and museology professors in particular. These professionals should hold undergraduate and graduate degrees as well as specialized qualifications that include new informational dimensions of museum documentation, making it available for socialization online based on its constitution as digital objects. 
In conclusion, it is important to emphasize that the reflections presented here have been put forward against a backdrop of greater social appreciation for and potential appropriation of museums as cultural institutions. Recent decades have seen considerable changes in society and the information dimension of communication networks has become highly relevant in contemporary socialization practices. The idea of a network society is expressed here as a decisive factor in the current context and this should be taken into account. As such, this phenomenon should be regarded as a necessary element in rethinking museums and their social function, with particular emphasis on the characteristics of museum education and their need for dialogue and interaction with the public. It is therefore essential to devise the means, conditions, and paths for this appropriation to occur and ensure that new experiences develop by broadening the conceptual and operational dimensions of museology itself.

The Brazilian experience described here, regarding the Tainacan project of the Brazilian Institute of Museums, demonstrates some possibilities and illustrates how digital culture can be appropriated in favour of museum education. The results are still preliminary, although intensified and accelerated in the context of the Covid-19 pandemic in 2020 and the consequent closure of institutions to the public. The experiences reported throughout this article demonstrate that museums have worked in other ways, keeping themselves engaged and active in digital networks with their audiences.

Nevertheless, it is noticeable in Brazil that many professionals have turned to actions in the digital environment without paying attention to the specificities and potentialities of the Internet, often just reproducing presential communication strategies online. This research intends to demonstrate that other forms and practices are possible, considering that the network has its own characteristics and socialization strategies that are inherent to it. It is fundamental for the educator to take ownership of these perspectives, which is already present in the very formulation of the National Policy of Museum Education, but still absent from the daily practice of professionals and many technical and graduate courses in the country. We believe that the connection between the principles formulated in PNEM and the conceptual perspectives of digital culture constitute practices and operational possibilities which can be implemented in the reality of Brazilian institutions.

Received: 25 June 2020

Finally accepted: 8 February 2021

\section{Notes}

1 The 1972 Round Table of Santiago (Chile) is considered the founding event of New Museology (Santos 2008; Bruno 2010).

2 It is possible to follow information on this project on the web page: https://www.museus. gov.br/acoes-e-programas/projeto-tainacan/.

3 To learn more about Tainacan application cases, see the web page of the project: https:// tainacan.org/casos-de-uso/.

4 https://glamtools.toolforge.org/glamorgan.html

5 https://pageviews.toolforge.org/?project=pt. wikipedia.org\&platform=all-access\&agent=u ser\&redirects $=0$ \&range=latest-90\&pages $=$ Lista de pinturas de Victor Meirelles

6 https://web.facebook.com/MuseusBR/?ref=page internal

7 https://support.google.com/knowledgepanel/answer/9163198?hl=en

8 For greater detail on discussions about the specificity of museum education based on the elements of museum pedagogy proposed by Van Praët and Poucet, see Martins (2011). 


\section{References}

Aidar, G. and Martins, L. (2018) 'Cultural Action in Museums: What do Professionals and Researchers think in the Latin American Context?', ICOM Education, 28 159-73.

Almeida, A., Studart, D. and Valente, M. (2003) 'Pesquisa de Público em Museus: desenvolvimento e perspectivas', in Guaracira Gouvêa, Martha Marandino and Maria Cristina Leal (eds) Educação e Museu: A construção social do caráter educativo dos museus de ciências, 129-57, Rio de Janeiro: Editora Access/Faperj.

Barbier, F. (2018), História das Bibliotecas: de Alexandria às Bibliotecas Virtuais, São Paulo: EdUSP.

Bizerra, A. (2009) 'Atividade de aprendizagem em museus de ciências', PhD thesis, Universidade de São Paulo, São Paulo.

Bruno, M. (1996) 'Museologia e comunicação', Cadernos de Sociomuseologia, 9 (9), Universidade Lusófona de Humanidades e Tecnologias. https://revistas.ulusofona. pt/index.php/cadernosociomuseologia/issue/view/26.

(2010) O ICOM-Brasil e o pensamento museológico brasileiro, volume 1, São Paulo: Pinacoteca, ICOM.

Burke, P. (2012) Uma história social do conhecimento II: da enciclopédia à Wikipédia, São Paulo: Editora Zahar.

Cameron, F. (2010) 'Beyond the Cult of the Replicant: Museums and Historical Digital Objects - Traditional Concerns, New Discourses', in Fiona Cameron and Sarah Kenderdine (eds) Theorizing Digital Cultural Heritage: A Critical Discourse, Cambridge: MIT Press.

Cazelli, S., Marandino, M. and Studart, D. (2003) ‘Educação e Comunicação em Museus de Ciências: aspectos históricos, pesquisa e prática', in Guaracira Gouvêa, Martha Marandino and Maria Cristina Leal (eds) Educação e Museu: A construção social do caráter educativo dos museus de ciências, 83-106, Rio de Janeiro: Editora Access/Faperj.

Comitê Gestor da Internet no Brasil (2020) Survey on the Use of Information and Communication Technologies in Brazilian Households: ICT Households 2019, 1st ed., Sao Paulo: Núcleo de Informação e Coordenação do Ponto BR. Cetic.br - Três em cada quatro brasileiros já utilizam a Internet, aponta pesquisa TIC Domicílios $\underline{2019}$.

Costa, A., Castro, F., Chiovatto, M. and Soares, O. (2018) 'Educação museal', in IBRAM (ed) Caderno da PNEM, 73-6, Brasília: IBRAM. https://www.museus.gov.br/wpcontent/uploads/2018/06/Caderno-da-PNEM.pdf.

Freire, P. (2013) Pedagogia do oprimido, 54th ed, Rio de Janeiro: Paz e Terra.

Geismar, H. (2018) Museum Object Lessons for the Digital Age, London: UCL Press.

Hooper-Greenhill, E. (1994) 'Education, Communication and Interpretation: Towards a Critical Pedagogy in Museums', in Eilean Hooper-Greenhill (ed) The Educational Role of the Museum, 3-25, London: Routledge.

IBRAM (2018) Caderno da Política Nacional de Educação Museal, Brasília: IBRAM. https://www.museus.gov.br/wp-content/uploads/2018/06/Caderno-da-PNEM.pdf. 
Lewi, H., Smith, W., Lehn, D. and Cooke, S. (2020) The Routledge International Handbook of New Digital Practices in Galleries, Libraries, Archives, Museums and Heritage Sites, London: Routledge.

Lindauer, M.A. (2007) 'Critical Museum Pedagogy and Exhibition Development: A Conceptual First Step', in Simon Knell, Suzanne MacLeod and Sheila Watson (eds) Museum Revolutions. How Museums Change and are Changed, 303-14, London: Routledge.

Martins, L.C. (2011) 'A constituição da educação em museus: o funcionamento do dispositivo pedagógico museal por meio de um estudo comparativo entre museus de artes plásticas, ciências humanas e ciência e tecnologia', PhD thesis, Universidade de São Paulo, São Paulo.

(2015) 'Como é criado o discurso pedagógico dos museus? Fatores de influência e limites para a educação museal', Museologia \& Interdisciplinaridade, 1 (6) 14-20.

(2018) 'Existe um currículo museal? As teorias curriculares na compreensão da educação em museus', Educação Temática Digital Campinas, 3 (20) 640-61.

Martins, D.L. (2018) 'As práticas da cultura digital', Revista do Centro de Pesquisa e Formação, 7, 51-60.

Navarrete, T. and Borowieck, K.J. (2015) 'Change in Access after Digitization: Ethnographic Collections in Wikipedia', ACEI Working Paper Series, 1-36. https:// ideas.repec.org/p/cue/wpaper/awp-10-2015.html

Roberts, L.C. (1997) From Knowledge to Narrative: Educators and the Changing Museum, Washington, London: Smithsonian Institution Press.

Santos, M.C. (2008) Encontros museológicos: Reflexões sobre a museologia, a educação e o museu, Rio de Janeiro: MINC/IPHAN/DEMU.

Van Präet, M. and Poucet, B. (1992) 'Les musées, lieux de contre-éducation et de partenariat avec l'école', Education \& Pédagogies - dés élèves au musée, 16 47-66.

Valente, M.E.A. (2003) 'A conquista do caráter publico do museu', in Guaracira Gouvêa, Martha Marandino and Maria Cristina Leal (eds) Educação e Museu: A construção social do caráter educativo dos museus de ciências, 21-46, Rio de Janeiro: Editora Access/Faperj.

Varine, H. (2013) As raízes do futuro, Porto Alegre: Editora Medianiz.

Vessuri, H. (2017) 'Museos en la transición digital ¿Nuevas asimetrías?', in Barbara Göbel and Gloria Chicote (eds) Transiciones inciertas: Archivos, conocimientos y transformación digital en América Latina, 37-55, La Plata: Universidad Nacional de La Plata. https://www.iai.spk-berlin.de/fileadmin/dokumentenbibliothek/Ausser der Reihe/ADR G\%C3\%B6bel Chicote 2017 Transiciones Inciertas.pdf

Winesmith, K. and Anderson, S. (2020) The Digital Future of Museums: Conversations and Provocations, London: Routledge. 
Authors:

Dr. Dalton Lopes Martins

Professor on the graduation course of Librarianship and in the Post Graduate Program in Information Science at the Faculty of Information Science at the University of Brasília (UnB). $\mathrm{He}$ holds a degree in Electrical Engineering from the State University of Campinas and a Master's degree in Computer Engineering from the State University of Campinas. Doctorate in Information Sciences at ECA-USP .

Address: Faculdade de Ciência da Informação da Universidade de Brasília (UNB). Campus Universitário Darcy Ribeiro,

Asa Norte,

Brasília (DF).

Zip code: 70.910-900.

Email: daltonmartins@unb.br

Phone number: +5562981318069

\section{Dr. Luciana Conrado Martins}

Graduate in History from the University of São Paulo, Master's in Education from the University of São Paulo (2006), a Master's Degree in Museology from Universidad de Valladolid and Specialist in Museology from CEMMAE-USP and PHD in Education also from the University of São Paulo. She owns the company named Percebe, where she develops consultancy for museums and cultural institutions. Professor at Universidade Federal do Piauí (UFPI)

Address: Percebe.

Rua Fradique Coutinho, 963 São Paulo (SP).

Zip code: 05416-011.

Email: lucianamartins@percebeeduca.com.br

Phone number :+5511993955868

Msc. Danielle do Carmo

Doctoral student in Information Science at the University of Brasília, Master's in Social Memory and Cultural Heritage by the Federal University of Pelotas, and graduated in History by the Federal University of Goiás.

Address : Faculdade de Ciência da Informação na Universidade de Brasília (UNB). Campus Universitário Darcy Ribeiro,

Asa Norte,

Brasília (DF).

Zip code: 70.910-900.

Email: docarmo.danielle@gmai.com

Phone number: +5562993528456 